\title{
Characteristics of the post-thawed Balinese bull semen extended in three different extenders and equilibration times
}

\author{
A. S. Amal ${ }^{1,2}$, R. I. Arifiantini ${ }^{3}, *$ M. A. Setiadi ${ }^{3}$ and S. Said ${ }^{4}$ \\ ${ }^{1}$ Post Graduate Program in Reproductive Biology, \\ Faculty of Veterinary Medicine, IPB University, Dramaga Campus, Bogor 16680 - Indonesia \\ ${ }^{2}$ Permanent Address: El Delta II El Salam City, Cairo, 11788 - Egypt \\ ${ }^{3}$ Reproduction and Obstetrics Division, Department of Veterinary Clinic, \\ Reproduction and Pathology, Faculty of Veterinary Medicine, IPB University, \\ Jl. Agatis Raya, Kampus IPB Dramaga, Bogor 16680, Indonesia \\ ${ }^{4}$ Research Center for Biotechnology, Indonesian Institute of Sciences (LIPI), \\ Jalan Raya Bogor Km 46, Cibinong, Bogor- Jakarta \\ *Corresponding E-mail: iis.arifiantinipurna@gmail.com
}

Received November 01, 2018; Accepted May 20, 2019

\begin{abstract}
ABSTRAK
Tujuan dari penelitian ini adalah untuk menguji efektivitas dari tiga macam bahan pengencer (Tris kuning telur, Bioxcell ${ }^{\circledR}$ dan Optixcell®) dan tiga waktu ekuilibrasi (T-30 min, T-2 jam dan T-4 jam) untuk kriopreservasi semen sapi bali. Tiga puluh enam ejakulat semen berasal dari 6 ekor sapi bali jantan dikoleksi dan dibekukan mengikuti protokol pembekuan rutin. Evaluasi motilitas sperma postthawing (PTM) dilakukan dengan computer assisted semen analysis (CASA). Integritas membran plasma dievaluasi dengan hypo-osmotic swelling (HOS) test dan viabilitas dievaluasi dengan pewarnaan eosin nigrosin. Hasil penelitian menunjukkan terdapat interaksi yang signifikan antara waktu ekuilibrasi dan pengencer terhadap motilitas, viabilitas dan integritas membran sperma sapi bali. Perlakuan kontrol (4 jam waktu ekuilibrasi) memiliki nilai tertinggi $(\mathrm{P}<0,05)$ dan perlakuan 30 menit waktu ekuilibrasi memiliki nilai terrendah $(\mathrm{P}<0,05)$ untuk total motilitas, motilitas progresif, persentase sperma dengan membran plasma utuh (MPU) dan viabilitas sperma. Motilitas, skor pergerakan individu dan integritas membran sperma dalam pengencer Optixcell ${ }^{\circledR}$ lebih tinggi dibandingkan dengan semen yang dibekukan dalam pengencer Bioxcell ${ }^{\circledR}$ dan Tris kuning telur. Motilitas total, progresif dan integritas membran sperma terbaik secara keseluruhan terdapat dalam pengencer Tris kuning telur dan Bioxcell ${ }^{\circledR}$ dengan waktu ekuilibrasi 4 jam dan Optixcell ${ }^{\circledR}$ dengan waktu ekuilibrasi 2 dan 4 jam. Kesimpulan berdasarkan analisis subyektif dan obyektif, equilibrasi 30 menit tidak cukup untuk mempertahankan motilitas dan integritas membran sperma yang lebih baik; equilibrasi untuk 2 jam menghasilkan motilitas sperma tertinggi untuk pengencer Optixcell ${ }^{\circledR}$; dan equilibrasi untuk 4 jam menghasilkan viabilitas tertinggi untuk semua pengencer yang digunakan.

Kata kunci: sapi bali, kriopreservasi semen, pengencer semen, waktu ekuilibrasi, CASA.
\end{abstract}

\begin{abstract}
The objectives of the present study were to compare and determine the best post-thawed characteristics of balinese bull sperm cryopreserved in three different extenders; animal based (Trisclarified egg yolk (Tris-cEY)), and non-animal based extenders (Bioxcell ${ }^{\circledR}$ (lecithin based) and
\end{abstract}


Optixcell ${ }^{\circledR}$ (liposome based)) in combination with three different equilibration times (30 minutes, 2 hours, 4hours). Thirty six ejaculates were collected from six Balinese bulls and frozen in three extenders (Tris-cEY, Bioxcell ${ }^{\circledR}$ and Optixcell ${ }^{\circledR}$ ) after equilibration in three different times (30 minutes, 2hours and 4hours). Computer-assisted sperm analysis (CASA), hypo-osmotic swelling test (HOST) and eosin nigrosin staining were used in the post-thawed semen analysis. There was a significant interaction between equilibration time and extender type for sperm motility, viability and membrane integrity. Thirty minutes equilibration time had the lowest values $(\mathrm{P}<0.05)$ for all the evaluated parameters independent of extender type. Overall, semen extended in Tris-cEY, Bioxcell ${ }^{\circledR}$ and Optixcell ${ }^{\circledR}$ were similarly better when equilibrated at 4 hours $(\mathrm{P}>0.05)$. Moreover, post-thawed semen which were extended in Optixcell ${ }^{\circledR}$ for 2 hours equilibration showed a better motility compared with the other extenders $(\mathrm{P}<0.05)$. In conclusion, two hours equilibration of semen with Optixcell ${ }^{\circledR}$ is sufficient for semen freezing. Four hours equilibration has the best sperm survival, independent of the extender type.

Keywords: Balinese bull, semen cryopreservation, semen extenders, equilibration time, CASA.

\section{INTRODUCTION}

Bali cattle (variously named Bos sondaicus, Bos javanicus, Bos bibos banteng) is considered as the most preferable breed in the small holding systems in Indonesia because of their high resistance against diseases, its remarkable ability to grow on low quality fodders and its high fertility rate (Purwantara et al., 2012 ). Bali cattle represent about $25 \%$ of the total cattle population in Indonesia, mainly inhabitant the Indonesian eastern islands and it is very important there in the smallholder farming businesses (Lisson et al., 2010).

In cattle, artificial insemination (AI) with frozen-thawed sperm is widely used for more than 30 years worldwide and intensively applied in Indonesia since 1970s (Sutarno and Setiawan 2016). When conducting AI in cattle breeding, cryopreserved insemination doses are used and, consequently, their quality plays an important role in the success of fertilization (Beran et al., 2013). However, in comparison with fresh semen, the quality of the frozen thawed semen is much lower hence, the fertility is still generally poorer with cryopreserved semen than with fresh semen (Watson, 2000).

Extenders contain nutritional and protective ingredients which are added to semen to preserve sperm fertilizing ability. Egg yolk is the most widely used extender component of mammalian sperm. Its role in protecting the frozen sperm is not fully clear however several researchers have suggested several mechanisms of action (Bergeron and Manjunath, 2006; Tonieto et al., 2010). However, the addition of egg yolk contributes to great variability among batches of extender and increases the risk of disease transmission (El-Sisy et al., 2016). Moreover, harmful metabolites and endotoxins could be contained in the egg yolk, that lead to negative effects on the viability of the sperm cells (Vidal et al., 2013), egg yolk also contains steroid hormones that lead to the reduction of sperm motility (El-Sisy et al., 2016).

It is supposed that the use of non-animal based extender could decrease the risk of pathogen transmission and would be preferred to be used instead of animal based extender if it efficiently preserve the post-thawed semen attributes. Bioxcell ${ }^{\circledR}$ is a commercially available soybean lecithin-based extender which used as a substitution for Egg Yolk but the results of using it for semen freezing are controversial. Another commercially available extender is Optixcell ${ }^{\circledR}$ which is synthetic liposome based extender; those liposomes are molecules which are characterized by being defined chemically, and having the ability to exchange lipids and cholesterol with the damaged portions of the sperm plasma membrane (Belala et al., 2016a; Ansari et al., 2016).

Equilibration time is considered as a necessary step in semen freezing. In most Indonesian national AI centers, a range of time between 4 hours and overnight is applied for semen/extender equilibration before freezing, such a step is considered as time consuming moreover, and it could lead to the increased oxidative reactions and Reactive Oxygen Species (ROS) formation which is so harmful for the sperm cell. So, there is a need to shorten the duration of this step with keeping high quality post-thawed sperm. Therefore, the objectives of the present study were to compare the postthawed characteristics including the total, progressive motilities, motility kinematics and plasma membrane integrity of Balinese bull sperm cryopreserved in three different extenders; animal 
based extender (Tris-clarified egg yolk (TriscEY), and non-animal based extender (Bioxcell ${ }^{\circledR}$ (lecithin based extender) and Optixcell ${ }^{\circledR}$ (liposome based extender)) in combination with three different equilibration times (30 minutes, 2 hours, 4hours).

\section{MATERIALS AND METHODS}

\section{Tris-clarified Egg Yolk, Bioxcell ${ }^{\circledR}$ and Optixcell ${ }^{\circledR}$ Extenders Preparation}

The aim of preparing Tris-clarified egg yolk (Tris-cEY) was to exclude the large yolk particles to avoid errors in semen evaluations. Commercially one day aged of commercial fresh eggs were collected, disinfected and manually cracked, yolks were separated from the albumin and were rolled carefully on a filter paper to remove chalazes and traces of albumin adhering to the vitelline membrane. That membrane was then disrupted with a scalpel blade and its content were collected in a beaker glass, and then it was added $20 \%$ to the basic Tris buffer formula according to Arifiantini and Yusuf (2010) as presented in Table 1. The mixture solutions were then centrifuged for 45 minutes at $12000 \mathrm{~g}$ at $4^{\circ} \mathrm{C}$. The supernatant was separated then used as TriscEY extender. Bioxcell ${ }^{\circledR}$ and Optixcell ${ }^{\circledR}$ were prepared according to the instruction pamphlet, Bioxcell ${ }^{\circledR}$ was diluted in aquabides $1: 4$ and Optixcell ${ }^{\circledR}$ was diluted in aquabides 1: 2 . The prepared extenders were kept in water bath at $33^{\circ} \mathrm{C}$ until the dilution step.

\section{Semen Collection and Processing}

Semen of six sexually active Balinese bulls 5-7 years old were collected twice a week using artificial vagina. The bulls were confined in tiestall barn for 24 hours, except several hours for exercise on the day of semen collection. All bulls were fed with forage or rice straw and $4 \mathrm{~kg}$ of concentrate per day with protein content of $16 \%$. Semen was evaluated visually for ejaculate volume, color and consistency. Sperm concentration was evaluated using photometer (SDM 6 Minitub, Germany) and sperm velocity parameters were evaluated using CASA (SpermVision Tm 3.7 Minitub, Germany). Semen with good quality and more than $70 \%$ sperm motility were selected for further treatments and freezing. Semen was divided and extended with three different types of extender; Tris-cEY, Bioxcell ${ }^{\circledR}$ and Optixcell ${ }^{\circledR}$ in such way that each insemination dose contained $100 \times 10^{6} \mathrm{sperm} / \mathrm{ml}$.
Semen was then automatically filled in 0.25 french straws. Equilibration of the straws containing the extended semen were carried out in a refrigerated cabinet $\left(4^{\circ} \mathrm{C}\right)$, straws from each extender were divided in to 3 groups according to the time of equilibration (30 minutes, 2 hours and 4 hours). The equilibrated straws from each treatment were then exposed to liquid nitrogen vapor $4 \mathrm{~cm}$ above the level of liquid nitrogen for 10 minutes before being immersed into liquid nitrogen $\left(-196^{\circ} \mathrm{C}\right)$ for storage and further evaluations.

\section{Automated Analysis of Semen Motility}

Post-thawed sperm motility was evaluated using Computer Assisted Sperm Analysis (CASA) (Sperm vision ${ }^{\mathrm{TM}} 3.7$ Minitub, Germany). CASA machine includes a software program (SpermVision) with settings adjusted for bull sperm which was attached to an Olympus BX 51 microscope (Olympus, Tokyo, Japan) with a heated stage $\left(37^{\circ} \mathrm{C}\right)$. The microscope was fitted with a 20x objective and a 10x eyepiece; the camera operates at 60 frames per second. Sperm samples alliquotes $(5 \mu \mathrm{l})$ of two straws of each treatment were pipetted on to a warm glass slide, and a coverslip was placed on top. The setting of CASA was held as presented in Table 2. The following parameters were evaluated for postthawed semen, namely: Motility: the percentage of motile sperm; Progressive motility: the percentage of progressively motile sperm; Curvilinear velocity (VCL: $\mu \mathrm{m} / \mathrm{second}$ ); Straight line velocity (VSL: $\mu \mathrm{m} / \mathrm{second}$ ); Average Path Velocity (VAP: $\mu \mathrm{m} / \mathrm{second}$ ) and Amplitude of Lateral Head Displacement (ALH: $\mu \mathrm{m}$ ); The

Table 1 Tris Buffer Composition*

\begin{tabular}{lc}
\hline Material & Amount \\
\hline Tris (hydroxymethyl) & 3.03 \\
aminomethane $(\mathrm{g})$ & 1.78 \\
Citric acid $(\mathrm{g})$ & 1.25 \\
Fructose $(\mathrm{g})$ & 6 \\
Glycerol $(\mathrm{ml})$ & 1 \\
Strepomycin $(\mathrm{mg}) / \mathrm{ml}$ & 1000 \\
Penicillin $(\mathrm{IU}) / \mathrm{ml}$ & 100 \\
\hline Aquabides $(\mathrm{ml})$ & \\
\hline
\end{tabular}

*Arifiantini and Yusuf (2010). 
Table 2. Parameter Settings for Computer-assisted Sperm Analysis (CASA)

\begin{tabular}{lc}
\hline \multicolumn{1}{c}{ Variables } & Units \\
\hline Particle size range & $20-100 \mu \mathrm{m} 2$ \\
Immotile sperm & $\mathrm{AOC}<5 ; \mathrm{BCF}<0.2 ; \mathrm{VSL}<0.2$ \\
Locally motile sperm & $\mathrm{DSL}<4.5$ \\
Hypermotile & $\mathrm{VCL}>80 ; \mathrm{LIN}<0.65 ;$ ALH $>6.5$ \\
Progressively motile sperm & $\mathrm{STR}>0.5 ;$ LIN $>0.35$ \\
\hline
\end{tabular}

$\mathrm{AOC}=$ average orientation change, $\mathrm{BCF}=$ beat cross frequancy, $\mathrm{VSL}=$ straight line velocity, $\mathrm{DSL}=$ distance straight line, $\mathrm{VCL}=$ curvilinear velocity, $\mathrm{LIN}=$ linearity, $\mathrm{STR}=$ straightness.

wobble of the sperm head (WOB) is measured as (VAP/VCL); the linearity of the curvilinear track (LIN) is measured as VSL/VCL. Another motion parameter the beat cross frequency (BCF) which describes the frequency of the sperm head crossing the average path of the sperm in Hertz.

\section{Assessment of Membrane Integrity and Sperm Viability}

Hypo-osmotic swelling (HOS) test was used for functional sperm membrane integrity assessment (Hossain et al., 1998). Two straws from each treatment were thawed in a water bath at $37^{\circ} \mathrm{C}$ for $30 \mathrm{sec}$. The thawed semen $(100 \mu \mathrm{L})$ was added to $1000 \mu \mathrm{L}$ of hypo-osmotic solution $(100 \mathrm{mOsm} / \mathrm{kg} \mathrm{H} 2 \mathrm{O})$ in an eppendorf tube, and then it was mixed gently and incubated for 45 minutes at $37^{\circ} \mathrm{C}$. The hypo-osmotic solution was prepared by mixing $0.9 \mathrm{~g}$ fructose with $0.49 \mathrm{~g}$ trisodium citrate dehydrate in $100 \mathrm{~mL}$ aqua-bides. After incubation, $15 \mu \mathrm{L}$ of well mixed sample was placed on a warm slide $\left(37^{\circ} \mathrm{C}\right)$ and covered with a cover slide, the sperm tails were observed under light microscopy (Olympus CK2, ULWCD 0.30) at 400x magnification (300 sperm per slide were observed). The sperm were classified as reacted and non-reacted depending on the status of the sperm tail plasma membrane. Sperm viability was assessed using Eosin-Nigrosin staining technique. Semen was mixed with eosin-nigrosin in a ratio of 1:4. After homogenization, slide smears were prepared and dried using heating table $\left(37^{\circ} \mathrm{C}\right)$. At least 300 sperms were counted in total 10 fields of the slide. Sperm were classified alive (colorless) and dead (red sperm head).

\section{Statistical Analysis}

A completely randomized design with two factors arrangement ( 3 extenders $\times 3$ equilibration times), with 6 repetitions was used. Results are presented as least square means \pm standard error of means (LS means \pm SEM). Effects of extender type and equilibration time were evaluated by ANOVA, with Duncan's multiple comparison post-hoc test was used to determine differences among treatment combinations. Differences with a P-value of 5\% were considered to be statistically significant. Values of sperm motility parameters, viability, and membrane integrity were compared using ANOVA. Calculations were performed with the statistical software package (SPSS 24).

\section{RESULTS}

\section{Post-thawed sperm motility (CASA evaluation)}

There were significant interactions between extender type and equilibration time for total and progressive motilities. Tris-cEY, Bioxcell ${ }^{\circledR}$ and Optixcell ${ }^{\circledR}$ with 30 minutes equilibration had the lowest values between among all treatment values $(\mathrm{P}<0.05)$, while semen which was extended in Tris-cEY and Bioxcell ${ }^{\circledR}$ with 2 hours equilibration time had lower values $(\mathrm{P}<0.05)$ than 4 hours. Motility and progressive motility of postthawed semen extended with Optixcell ${ }^{\circledR}$ at 2hours $60.35 \pm 1.25$ and $55.79 \pm 1.64 \%$ respectively and 4hours equilibrations $59.52 \pm 1.9$ and $55.73 \pm 2.07 \%$ respectively were not significantly different (Table 3 ).

There were no interactions between extender type and equilibration time for the other parameters evaluated by CASA (VAP, VSL, VCL, ALH, BCF, WOB, LIN). Moreover, sperm motion kinematics, namely, VSL, VAP, ALH and BCF were not affected by different equilibration times $(\mathrm{P}>0.05)$, however, those parameters were 
Table 3. Mean \pm SEM of Total and Progressive Motilities (CASA) of Balinese Bull Semen Cryopreserved using Three Extenders and Equilibration Times

\begin{tabular}{|c|c|c|c|}
\hline Variable & Equilibration Time & Extender Type & Results \\
\hline \multirow[t]{9}{*}{ Total motility (\%) } & \multirow[t]{3}{*}{30 minutes } & Tris-cEY & $31.20 \pm 1.25^{\mathrm{d}}$ \\
\hline & & Bioxcell ${ }^{\circledR}$ & $27.87 \pm 1.46^{\mathrm{d}}$ \\
\hline & & Optixcell ${ }^{\circledR}$ & $46.32 \pm 2.05^{b c}$ \\
\hline & \multirow[t]{3}{*}{2 hours } & Tris-cEY & $42.68 \pm 1.16^{\mathrm{c}}$ \\
\hline & & Bioxcell $\AA$ & $49.06 \pm 1.93^{\mathrm{b}}$ \\
\hline & & Optixcell ${ }^{\circledR}$ & $60.35 \pm 1.25^{\mathrm{a}}$ \\
\hline & \multirow[t]{3}{*}{4 hours } & Tris-cEY & $56.38 \pm 2.19^{\mathrm{a}}$ \\
\hline & & Bioxcell® & $56.12 \pm 2.35^{\mathrm{a}}$ \\
\hline & & Optixcell® & $59.52 \pm 1.90^{\mathrm{a}}$ \\
\hline \multirow[t]{9}{*}{ Progressive motility (\%) } & \multirow[t]{3}{*}{30 minutes } & Tris-cEY & $27.89 \pm 1.28^{\mathrm{d}}$ \\
\hline & & Bioxcell ${ }^{\circledR}$ & $24.71 \pm 1.50^{\mathrm{d}}$ \\
\hline & & Optixcell® & $40.62 \pm 2.20^{\mathrm{bc}}$ \\
\hline & \multirow[t]{3}{*}{2 hours } & Tris-cEY & $38.96 \pm 1.23^{\mathrm{c}}$ \\
\hline & & Bioxcell ${ }^{\circledR}$ & $44.18 \pm 2.10^{b}$ \\
\hline & & Optixcell ${ }^{\circledR}$ & $55.79 \pm 1.64^{\mathrm{a}}$ \\
\hline & \multirow[t]{3}{*}{4 hours } & Tris-cEY & $51.72 \pm 1.99^{\mathrm{a}}$ \\
\hline & & Bioxcell ${ }^{\circledR}$ & $50.28 \pm 2.50^{\mathrm{a}}$ \\
\hline & & Optixcell ${ }^{\circledR}$ & $55.73 \pm 2.07^{\mathrm{a}}$ \\
\hline
\end{tabular}

Tris-cEY $=$ Tris Clarified Egg Yolk. Means in the same column of the same variable with different superscript are significantly different $(\mathrm{P}<0.05)$.

affected by the extender type. Both VSL and VAP values were the highest with semen cryopreserved with Bioxcell ${ }^{\circledR}$ and Optixcell ${ }^{\circledR}$ (VSL: $53.84 \pm 1.52, \quad 54.93 \pm 1.1 \mu \mathrm{m} / \mathrm{s}$, VAP: $69.46 \pm 1.7$, $73.28 \pm 1.15 \mu \mathrm{m} / \mathrm{s}$ ) respectively in compare with Tris-cEY (VSL: $45.08 \pm 1.01 \mu \mathrm{m} / \mathrm{s}$, VAP: $60.28 \pm 1.36 \mu \mathrm{m} / \mathrm{s})(\mathrm{P}<0.05)$ as presented in Table 4.

ALH value had the lowest value in semen cryopreserved with Bioxcell® $(3.98 \pm 0.14 \mu \mathrm{m})$, $(\mathrm{P}<0.05)$ in compare with both Tris-cEY and Optixcell ${ }^{\circledR}(5.79 \pm 0.19,5.58 \pm 0.17 \mu \mathrm{m})$. However, BCF was significantly different $(\mathrm{P}<0.05)$ between the three extenders used for semen cryopreservation with the highest value for Bioxcell ${ }^{\circledR} 28.48 \pm 0.71 \mathrm{~Hz}$ and the lowest value for Tris-cEY was $22.11 \pm 0.69 \mathrm{~Hz}$ while the value of Optixcell ${ }^{\circledR} \quad$ was $25.72 \pm 0.48 \mathrm{~Hz}$. LIN was significantly affected by extender type with the highest values for Bioxcell ${ }^{\circledR} 0.52 \pm 0.01$ and the lowest values for Optixcell ${ }^{\circledR} 0.42 \pm 0.01$ (Table 4). VCL was significantly affected by the extender type. VCL value was the highest for Optixcell ${ }^{\circledR}$ $(126.71 \pm 2.2 \mu \mathrm{m} / \mathrm{s})$ and the lowest for Tris-cEY and Bioxcell ${ }^{\circledR}$, those were $98.34 \pm 2.69$ and $103.22 \pm 2.88 \mu \mathrm{m} / \mathrm{s}$, respectively (Table 4 ).

\section{Post- thaw Membrane Integrity and Viability}

There was significant interactions between extender type and equilibration time for sperm viability and membrane integrity $(\mathrm{P}<0.05)$. TriscEY, Bioxcell ${ }^{\circledR}$ and Optixcell ${ }^{\circledR}$ with 30 minutes equilibration had the lowest values for sperm viability and membrane integrity compared between 2 hours and 4 hours equilibration. Sperm membrane integrity of semen extended in 
Table 4. Mean \pm SEM CASA Analysis of Sperm Motility Parameters of Balinese Bull Semen Cryopreserved using Three Extenders and Equilibration Times

\begin{tabular}{|c|c|c|c|c|c|}
\hline \multirow{2}{*}{ Variable } & \multirow{2}{*}{ Extender } & \multicolumn{3}{|c|}{ Equilibration Time } & \multirow{2}{*}{ Average } \\
\hline & & 30 minutes & 2 hours & 4 hours & \\
\hline \multirow[t]{3}{*}{$\operatorname{VSL}(\mu \mathrm{m} / \mathrm{s})$} & Tris-cEY & $45.16 \pm 2.19$ & $44.18 \pm 1.25$ & $45.91 \pm 1.86$ & $45.08 \pm 1.0^{b}$ \\
\hline & Bioxcell® & $54.46 \pm 2.48$ & $57.72 \pm 1.31$ & $49.34 \pm 3.15$ & $53.84 \pm 1.5^{\mathrm{a}}$ \\
\hline & Optixcell® & $55.26 \pm 1.76$ & $54.18 \pm 2.08$ & $55.36 \pm 2.08$ & $54.93 \pm 1.1^{\mathrm{a}}$ \\
\hline \multirow[t]{3}{*}{$\operatorname{VCL}(\mu \mathrm{m} / \mathrm{s})$} & Tris-cEY & $88.41 \pm 3.47$ & $102.62 \pm 3.03$ & $103.99 \pm 5.35$ & $98.34 \pm 2.7^{b}$ \\
\hline & Bioxcell® & $100.36 \pm 4.84$ & $108.82 \pm 3.75$ & $100.49 \pm 6.13$ & $103.2 \pm 2.9^{b}$ \\
\hline & Optixcell ${ }^{\circledR}$ & $123.20 \pm 3.99$ & $122.9 \pm 3.43$ & $134.04 \pm 2.89$ & $126.7 \pm 2.2^{\mathrm{a}}$ \\
\hline \multirow[t]{3}{*}{$\operatorname{VAP}(\mu \mathrm{m} / \mathrm{s})$} & Tris-cEY & $57.38 \pm 2.51$ & $61.04 \pm 1.84$ & $62.44 \pm 2.57$ & $60.28 \pm 1.4^{c}$ \\
\hline & Bioxell $\AA$ & $75.70 \pm 1.7$ & $70.33 \pm 1.34$ & $62.33 \pm 3.28$ & $69.46 \pm 1.7^{b}$ \\
\hline & Optixcell ${ }^{\circledR}$ & $72.16 \pm 2.12$ & $71.96 \pm 2.12$ & $75.72 \pm 1.7$ & $73.28 \pm 1.2^{\mathrm{a}}$ \\
\hline \multirow[t]{3}{*}{$\mathrm{BCF}(\mathrm{Hz})$} & Tris-cEY & $22.01 \pm 1.70$ & $21.62 \pm 0.67$ & $22.71 \pm 1.11$ & $22.11 \pm 0.7$ \\
\hline & Bioxcell® & $29.03 \pm 1.33$ & $29.61 \pm 1.15$ & $26.80 \pm 1.13$ & $28.48 \pm 0.7^{\mathrm{a}}$ \\
\hline & Optixcell@ & $26.36 \pm 0.57$ & $25.46 \pm 1.04$ & $25.36 \pm 0.89$ & $25.72 \pm 0.5^{b}$ \\
\hline \multirow[t]{3}{*}{$\mathrm{ALH}(\mu \mathrm{m})$} & Tris-cEY & $5.50 \pm 0.30$ & $6.06 \pm 0.25$ & $5.81 \pm 0.42$ & $5.79 \pm 0.2^{\mathrm{a}}$ \\
\hline & Bioxcell® & $3.95 \pm 0.32$ & $4.01 \pm 0.25$ & $4.00 \pm 0.16$ & $3.98 \pm 0.1^{\mathrm{b}}$ \\
\hline & Optixcell ${ }^{\circledR}$ & $5.37 \pm 0.29$ & $5.54 \pm 0.37$ & $5.84 \pm 0.25$ & $5.58 \pm 0.2^{a}$ \\
\hline \multirow[t]{3}{*}{ WOB (VAP/VCL) } & Tris-cEY & $0.65 \pm 0.01$ & $0.59 \pm 0.01$ & $0.6 \pm 0.01$ & $0.61 \pm 0.01^{\mathrm{b}}$ \\
\hline & Bioxcell ${ }^{\circledR}$ & $0.65 \pm 0.01$ & $0.65 \pm 0.02$ & $0.62 \pm 0.01$ & $0.64 \pm 0.01^{\mathrm{a}}$ \\
\hline & Optixcell ${ }^{\circledR}$ & $0.58 \pm 0.01$ & $0.56 \pm 0.01$ & $0.56 \pm 0.01$ & $0.57 \pm 0.01^{\mathrm{c}}$ \\
\hline \multirow[t]{3}{*}{ LIN (VSL/VAP) } & Tris-cEY & $0.51 \pm 0.01$ & $0.43 \pm 0.01$ & $0.44 \pm 0.02$ & $0.46 \pm 0.01^{\mathrm{c}}$ \\
\hline & Bioxcell® & $0.53 \pm 0.02$ & $0.53 \pm 0.02$ & $0.49 \pm 0.01$ & $0.52 \pm 0.01^{\mathrm{a}}$ \\
\hline & Optixcell ${ }^{\circledR}$ & $0.45 \pm 0.01$ & $0.42 \pm 0.01$ & $0.41 \pm 0.01$ & $0.42 \pm 0.01^{\mathrm{b}}$ \\
\hline
\end{tabular}

Tris-cEY $=$ Tris Clarified Egg Yolk. VSL=Straight line velocity $(\mu \mathrm{m} / \mathrm{second}), \mathrm{VCL}=$ Curvilinear velocity $(\mu \mathrm{m} / \mathrm{second}), \mathrm{VAP}=$ Average Path Velocity $(\mu \mathrm{m} / \mathrm{second}), \mathrm{BCF}=$ beat cross frequency $(\mathrm{Hz}), \mathrm{ALH}=$ Amplitude of Lateral Head Displacement $(\mu \mathrm{m})$, WOB $=(\mathrm{VAP} / \mathrm{VCL})$ The wobble of the sperm head, LIN= (VSL/VCL)linearity of the curvilinear track. Means in the same column with different superscript differed significantly $(\mathrm{P}<0.05)$.

Optixcell ${ }^{\circledR}$ at 4 hours equilibration was significantly higher in its functional membrane integrity than Tris-cEY and Bioxcell® (Table 5).

\section{DISCUSSION}

Sperm ability to be progressively motile is believed to be the most important sperm attribute for assessing the fertility potential of the cryopreserved semen. CASA systems were developed to minimize the errors of subjective assessment of sperm motility. Kathiravan et al. (2011) reported that only the parameters VCL, VSL, VAP can be used to predict in vivo fertility. More recent report suggested that sperm motion characteristics, such as total motility, progressive motility or BCF, were found to be predictors of bovine in vivo fertility (Oliveira et al., 2013). 
Table 5. Mean \pm SEM Sperm Viability and Membrane Integrity of Balinese Bull Semen Cryopreserved using Three Extenders and Equilibration Times

\begin{tabular}{|c|c|c|c|}
\hline Variable & Equilibration Time & Extender Type & Results \\
\hline \multirow[t]{9}{*}{ Viability (\%) } & \multirow[t]{3}{*}{30 minutes } & Tris-cEY & $29.92 \pm 2.24^{\mathrm{e}}$ \\
\hline & & Bioxcell ${ }^{\circledR}$ & $39.12 \pm 2.40^{\mathrm{d}}$ \\
\hline & & Optixcell® & $37.81 \pm 2.70^{\mathrm{d}}$ \\
\hline & \multirow[t]{3}{*}{2 hours } & Tris-cEY & $48.62 \pm 2.19^{b c}$ \\
\hline & & Bioxcell $®$ & $45.87 \pm 1.98^{\mathrm{c}}$ \\
\hline & & Optixcell® & $54.40 \pm 1.70^{\mathrm{ab}}$ \\
\hline & \multirow[t]{3}{*}{4 hours } & Tris-cEY & $56.75 \pm 2.37^{\mathrm{a}}$ \\
\hline & & Bioxcell $®$ & $56.50 \pm 1.90^{\mathrm{a}}$ \\
\hline & & Optixcell ${ }^{\circledR}$ & $59.22 \pm 1.65^{\mathrm{a}}$ \\
\hline \multirow[t]{9}{*}{ HOST $(\%)$} & \multirow[t]{3}{*}{30 minutes } & Tris-cEY & $38.04 \pm 1.89^{\mathrm{d}}$ \\
\hline & & Bioxcell $®$ & $39.02 \pm 1.90^{\mathrm{d}}$ \\
\hline & & Optixcell® & $41.51 \pm 2.10^{\mathrm{d}}$ \\
\hline & \multirow[t]{3}{*}{2 hours } & Tris-cEY & $50.53 \pm 1.54^{\mathrm{c}}$ \\
\hline & & Bioxcell ${ }^{\circledR}$ & $50.37 \pm 2.24^{\mathrm{c}}$ \\
\hline & & Optixcell ${ }^{\circledR}$ & $53.70 \pm 1.80^{\mathrm{bc}}$ \\
\hline & \multirow[t]{3}{*}{4 hours } & Tris-cEY & $56.95 \pm 1.80^{\mathrm{ab}}$ \\
\hline & & Bioxcell $\AA$ & $52.85 \pm 1.53^{\mathrm{bc}}$ \\
\hline & & Optixcell $®$ & $59.83 \pm 1.70^{\mathrm{a}}$ \\
\hline
\end{tabular}

Tris-cEY = Tris Clarified Egg Yolk. HOST= hypo-osmotic swelling test. Means in the same column of the same variable with different script are significantly different $(\mathrm{P}<0.05)$.

In the present research, the total and progressive motilities were the lowest at 30 minutes compared between 2 hours and 4 hours equilibration times, which confirmed that equilibration for 30 minutes was not sufficient to preserve sperm motility such a result is consistent with the report of Belala et al. (2016a). Vishwanath and Shannon (2000) suggested that 4 hours equilibration time was considered important for glycerol/sperm equilibration; however, glycerol penetrates the bull sperm pretty rapidly so other reasons could be causing such long equilibration time

Longer equilibration time is assumed to be needed for better frozen-thawed sperm quality that is because of the need of sperm plasma membrane to adapt with the membrane stabilizing agents contained in the extenders and the cooling temperature $\left(4^{\circ} \mathrm{C}\right)$. In the study by Leite et al. (2010), zero equilibration time resulted in significantly low post-thawed sperm motility, compared to equilibration times of either 2 or 4 hours. It has been reported that the best equilibration time in buck semen was 2 hours (Sundaraman and Edwin 2008), between 2 to 4 hours in boar (Schäfer et al., 2017), 4 hours for bulls (Leite et al., 2010) and 6 hours for dog (Belala et al., 2016b).

Liposome based extender (Optixcell $\AA$ ) had the highest values for motility and progressive motility while both Tris-cEY and Bioxcell ${ }^{\circledR}$ were not significantly different $(\mathrm{P}<0.05)$. No differences between post-thawed sperm motility in semen which were extended with Optixcell ${ }^{\circledR}$ at 2 hours and 4 hours, Lima-verde et al. (2017) revealed that sperm bull extended with 
Optixcell ${ }^{\circledR}$ has improved mitochondrial membrane potential compared to soy-lecithin extender. Moreover, semen extended in Optixcell ${ }^{\circledR}$ had improved motility kinematic parameters than semen extended in Tris-cEY and Bioxcell® such a finding as previously suggested by Kumar et al. (2015), Ansari et al. (2016) and Murphy et al. (2018). Liposomes behave similar to the cell membrane and adhere to the sperm membrane during cryopreservation, ensuring the exchange of cholesterol and phospholipids (Ansari et al., 2016). The protective activity of lecithin based extender could be due to the presence of a mixture of phosphatidylcholin and several fatty acids that protect sperm plasma membrane during freezing. However, in comparison with Optixcell ${ }^{\circledR}$, Bioxcell ${ }^{\circledR}$ extender is characterized by having an opaque color, the reason could be because of the larger particles it contains. Such particles would need more time to distribute around each sperm cell and to adapt with the cooling temperature, it could also have negative effects on the sperm motility attributes. Moreover, the post-thawed semen quality of semen extended with lecithin based extender still controversial (Leite et al., 2010; Crespilho et al., 2012, Singh et al., 2017, Lima-verde et al., 2018).

Equilibration time was significantly affecting the total and progressive motility. Controversially, there was no significant effect on other characteristics of sperm kinetics (i.e. sperm motion velocities (VAP, VSL, VCL), sperm head wobble characteristics (ALH, BCF) and sperm velocity ratio (LIN). Another notable finding was that the extender type had a significant effect on the sperm kinetics parameters. That could be assuming that the extender type composition had a direct effect on sperm velocity parameters than the duration of equilibration time. The differences in the motility kinematics obtained with the three studied extenders could be related to their qualitative composition which differs in terms of membrane stabilizing and energy providing agents. Variables of LIN, WOB, and BCF were with the highest values in semen frozen with Bioxcell ${ }^{\circledR}$. Variables of VCL, VSL, and VAP were with the highest values in semen frozen with Optixcell®. A previous report assumed positive correlation between Catalonian donkey sperm VCL and its ability to in-vitro penetrate zona pellucida-free bovine oocytes (Taberner et al., 2010). Another report presumed that VCL is related to the ability of sperm to penetrate cervical mucus (Robayo et al., 2008). Moreover, Gillan et al. (2008) suggested that the post-thawed sperm VSL is related directly to the bull fertility. Therefore, in the present study, a higher value of VCL and VSL in liposome-based extender might contribute towards better post-thawed semen quality and fertility such assumption was in accordance with Singh et al. (2017) and Murphy et al. (2018).

ALH was greater in Tris-cEY and Optixcell ${ }^{\circledR}$ than in a Bioxcell ${ }^{\circledR}$, which is in contrast with a preceding report held by Celeghini et al. (2008). Overall, greater values of VCL with ALH is not desired (ALH $\geq 7 \mu \mathrm{m}, \mathrm{VCL} \geq 70 \mu \mathrm{m}$ ), because it indicate hyper-activated sperms (Kathidravan et al., 2011). Moreover, according to Celeghini et al. (2008), a higher value of ALH indicates inferior quality of sperm and can disturb the cell cycle progression.

Semen cryopreserved with Bioxcell ${ }^{\circledR}$ and Optixcell ${ }^{\circledR}$ had greater BCF which explains the higher velocity values and suggesting that both extenders contain components that effectively keep the sperm flagellar structure intact, moreover, some of those components stimulate the mitochondrial ATP production and consequently beat frequency (Celeghini et al., 2008). For LIN, Optixcell® had lesser values at all times which indicate a higher amplitude of curvilinear path and direction similar to the path in a straight line but it is unclear its effect on sperm fertility (Januskauskas et al., 2003).

Many studies have been done comparing the protective capability of using plant-based extender and egg yolk based extender with controversial results (Leite et al., 2010, Singh et al., 2017). Some studies suggested that semen frozen in lecithin based extender showed decrease in its post-thawed motility, viability and acrosome integrity in compare with egg yolk extender (Celeghini et al., 2008, Crespilho et al., 2012). On the other hand, some studies have found a greater sperm total motility and acrosomal integrity when cryopreserved semen was extended with lecithinbased extender as compared with egg yolk extender (Chaudhari et al., 2015). Liposomes based extender is characterized by having the lowest sanitary risks, being chemically defined, calibrated and standardized. (Pillet et al., 2012). Singh et al. (2017) revealed that liposome based extender is better than animal protein (egg yolk) and soya lecithin-containing extenders as measured by field trials and functional sperm parameters.

Sperm membrane is the main site of damage 
from freezing process because of the freezing deteriorating effect on the sperm phospholipids and the loss of cholesterol. (Sieme et al., 2015). In the present study, hypo-osmotic swelling (HOS) test was used as a predictor of the functional integrity of sperm plasma membrane in sperm tail area. The principle of HOST is that the functional sperm tail plasma membrane will coil in the hypoosmotic media however the non-functional or the damaged plasma membrane will not react and the sperm tail stay straight.

Equilibration time and extender type had a significant effect on the post-thawed integrity of sperm membrane and sperm viability. Thirty minutes equilibration was not enough to preserve both sperm intact plasma membrane and viability in compare with four hours equilibration. Within treatment combinations, despite no differences between post-thawed sperm motility in semen which were extended with Optixcell ${ }^{\circledR}$ at 2 hours and 4hours equilibrations, there were significant differences for viability and plasma membrane integrity that could be because Optixcell® 2hours equilibration was not sufficient for sperm plasma membrane to be adapted with the cryoprotective components in the extender that could explain that the least membrane damage and highest viability was indicated at 4hours, independent of extender type. It is supposed that equilibration time facilitated adaptation of sperm membranes and metabolism to cold rather than to glycerol, that make the sperm to be less susceptible to freezing damage (Leite et al., 2010).

\section{CONCLUSION}

In conclusion, based on the objective analyses, in case of using Tris-cEY or Bioxcell ${ }^{\circledR}$ as extenders for Balinese bull sperm, shorter times equilibration like 30 minutes or 2 hours is not recommended because of the drastic decrease in the post-thawed semen motility. In case of using Optixcell ${ }^{\circledR}$ as semen extender, 2 hours is sufficient for maintaining the post-thawed semen quality. Semen equilibration at 4 hours has the greatest sperm survival, independent of the used extender type.

\section{ACKNOWLEDGMENTS}

This paper is supported by USAID through Sustainable Higher Education Research Alliances (SHERA) Program - Center for Collaborative Research Animal Biotechnology and Coral Reef
Fisheries (CCR ANBIOCORE). This research is partially funded by Developing Countries Partnership 2016 (Kemitraan Negara Berkembang, KNB).

\section{CONFLICT OF INTEREST}

The authors declare that there is no conflict of interests.

\section{REFERENCES}

Ansari, M.S., B.A. Rakha, S. Akhter and M. Ashiq. 2016. Optixcell improves the post thaw quality and fertility of buffalo bull sperm. Theriogenology 58:528-532.

Arifiantini, R.I and T.L. Yusuf. 2010. Developing of tris soy milk diluent for Frisian Holstein bull frozen semen. Hayati J. Biosci. 17:9194.

Belala, R., J. Delay, L. Amirat, M.H. Ropers, J.L. Guillou, M. Anton and D. Bencharif. 2016a. The benefits of liposomes for chilling canine sperm for 4 days at $4^{\circ} \mathrm{C}$. Anim. Reprod. Sci. 168:100-109.

Belala, R., L. Briand-Amirat, L. Vinciguerra, D. Tainturier, R. Kaidi, C. Thorin, S. Michaud, M. Anton and D. Bencharif. 2016b. Effect of equilibration time on the motility and functional integrity of canine spermatozoa frozen in three different extenders. Theriogenology 106:66-73.

Beran, J., L. Stadnik, J. Duchacek, M. Okrouhla, M. Doleza $\neg$ lova, V. Kadlecova and M. Ptacek. 2013. Relationships among the cervical mucus urea and acetone, accuracy of insemination timing, and sperm survival in Holstein cows. Anim. Reprod. Sci. 142:28-34.

Bergeron, A and P. Manjunath. 2006. New insights towards understanding the mechanisms of sperm protection by egg yolk and milk. Mol. Reprod. Dev. 73:13381344.

Celeghini, E.C.C., R.P. Arruda, A.F.C. Andrade, J. Nascimento, C.F. Raphael and P.H.M. Rodrigues. 2008. Effects that bovine sperm cryopreservation using two different extenders has on sperm membranes and chromatin. Anim. Reprod. Sci. 104:119-131.

Chaudhari, D.V., A. J. Dhami, K.K. Hadiya and J.A. Patel. 2015. Relative efficacy of egg yolk and soya milk-based extenders for cryopreservation. Vet. World. 8:239-244. 
Crespilho, A., M. Sá Filho, J. Dell'Aqua, M. Nichi, G. Monteiro, B. Avanzi, A. Martins and F.O. Papa. 2012. Comparison of in vitro and in vivo fertilizing potential of bovine semen frozen in egg yolk or new lecithin based extenders. Livest. Sci. 149:1-6.

El-Sisy, G.A., W.S. El-Nattat, R.I. Sheshtawy and A.M.A. El-Maaty. 2016. Substitution of egg yolk with different concentrations of soybean lecithin in tris-based extender during bulls semen preservability. Asian Pac. J. Reprod. 5:514-518.

Gillan, L., T. Kroetsch, W.M. Maxwell and G. Evans. 2008. Assessment of in vitro sperm characteristics in relation to fertility in dairy bull. Anim. Reprod. Sci. 103:201-214.

Hossain, A.M., B. Rizk, S. Barik, C. Huff and I.H. Thorneycroft. 1998. Time course of hypoosmotic swellings of human spermatozoa: evidence of ordered transition between swelling subtypes. Hum. Reprod. 13:15781583.

Januskauskas, A., A. Johannisson and $H$. Rodriguez-Martinez. 2003. Subtle membrane changes in cryopreserved bull semen in relation with sperm viability, chromatin structure, and field fertility. Theriogenology 60:743-758.

Kumar, P., M. Saini, D. Kumar, A. Balhara, S. Yadav, P. Singh and P. Yadav. 2015. Liposome-based semen extender is suitable alternative to egg yolk-based extender for cryopreservation of buffalo (Bubalus bubalis) semen. Anim. Reprod. Sci. 159:3845.

Kathiravan, P., J. Kalatharan, G. Karthikeya, K. Rengarajan and G. Kadirvel. 2011. Objective sperm motion analysis to assess dairy bull fertility using computer-aided system-a review. Reprod. Domest. Anim. 46:165-172

Leite, T.G., V.R. do Vale Filho, R.P. de Arruda, A.F.C. de Andrade and V.J. de Andrade. 2010. Effects of extender and equilibration time on post-thaw motility and membrane integrity of cryopreserved Gyr bull semen evaluated by CASA and flow cytometry. Anim. Rreprod. Sci. 120:31-38.

Lima-Verde, I.B., A. Johannisson, T. Ntallaris, E. Al-Essawe, Z. Al-Kass and J.M. Morrell. 2018. Effect of freezing bull semen in two non-egg yolk extenders on post-thaw sperm quality. Reprod. Dom. Anim. 53:127-136.

Lisson, S., N. MacLeod, C. McDonald, J.
Corfield, B. Pengelly and K. Puspadi. 2010. A participatory, farming systems approach to improving Bali cattle production in the smallholder crop-livestock systems of Eastern Indonesia. Agric. Sys. 103:486-497.

Murphy, E.M., C.O Meara, B. Eivers, P. Lonergan and S. Fair. 2018. Comparison of plant-and egg yolk-based semen diluents on in vitro sperm kinematics and in vivo fertility of frozen-thawed bull semen. Anim. Reprod. Sci. 191:70-75.

Oliveira, L.Z., R.P. de Arruda, A.F.C. de Andrade, E.C.C. Celeghini, P.D. Reeb and V.F.M. H. de Lima. 2013. Assessment of in vitro sperm characteristics and their importance in the prediction of conception rate in a bovine timed-AI program. Anim. Reprod. Sci. 137:145-155.

Pillet, E., C. Labbe, F. Batellier, G. Duchamp, V. Beaumal and M. Magistrini. 2012. Liposomes as an alternative to egg yolk in stallion freezing extender. Theriogenology 77: 268-279.

Purwantara, B., R.R. Noor, G. Andersson and H. Rodriguez-Martinez. 2012. Banteng and Bali cattle in Indonesia: status and forcasts. Reprod. Dom. Anim. 47:2-6.

Robayo, I., V. Montenegro, C. Valdis and J.F. Cox. 2008. CASA assessment of kinematic parameters of ram spermatozoa and their relationship to migration efficiency in ruminant cervical mucus. Reprod. Dom. Anim. 43:393-399.

Schäfer, J., D. Waberski, M. Jung and M. Schulze. 2017. Impact of holding and equilibration time on post-thaw quality of shipped boar semen. Anim. Reprod. Sci. 187:109-115.

Sieme, H., H. Oldenhof and W.F. Wolkers. 2015. Sperm Membrane Behaviour during Cooling and Cryopreservation. Reprod. Dom. Anim. 50:20-26.

Singh, A.K., A. Kumar, M. Honparkhe, S. Kaur, H. Kaur, S.P.S. Ghuman and P. S. Brar. 2017. Comparison of in vitro and in vivo fertilizing potential of buffalo bull semen frozen in egg yolk-, soya bean lecithin-and liposome-based extenders. Reprod. Dom. Anim. 53:195-202.

Sundaraman, M.N. and M.J. Edwin. 2008. Changes in Motility Characteristics of Goat Spermatozoa During Glycerol Equilibration and the Relevance to Cryopreservation. Asian J. Cell Biol. 3:22-23.

Sutarno and A.D. Setiawan. 2016. Review: The 
diversity of local cattle in Indonesia and the efforts to develop superior indigenous cattle breeds. J. Biodiversitas. 17:275-295.

Taberner, E., R. Morató, T. Mogas and J. Miró. Ability of Catalonian donkey sperm to penetrate zona pellucida-free bovine oocytes matured in vitro. Anim. Reprod. Sci. 118:354-361.

Tonieto, R.A., K.L. Goularte, G.D.A. Gastal, R.S. Schiavon, J.C. Deschamps and T. Lucia Jr. 2010. Cryoprotectant effect of trehalose and low-density lipoprotein in extenders for frozen ram semen. Small Rumin. Res.
93:206-209.

Vidal, A.H., A.M. Batista, E.C.B. da Silva, W.A. Gomes, S.V. Silva and M.M.P. Guerra. 2013. Soybean lecithin-based extender as an alternative for goat sperm cryopreservation. Small Rumin. Res. 109:47-51.

Vishwanath, R. and P. Shannon. 2000. Storage of bovine semen in liquid and frozen state. Anim. Reprod. Sci. 62:23-53.

Watson, P.F. 2000. The causes of reduce fertility with cryopreserved semen. Anim. Reprod. Sci. 60:481-492. 